\title{
MASicii
}

\section{Radioisotope Distribution Program Progress Report for August 1979}

\author{
E. Lamb
}

Access to the information in this report is limited to those indicated on the distribution list and to Department of Energy and Department of Energy Contractors 


\section{DISCLAIMER}

This report was prepared as an account of work sponsored by an agency of the United States Government. Neither the United States Government nor any agency Thereof, nor any of their employees, makes any warranty, express or implied, or assumes any legal liability or responsibility for the accuracy, completeness, or usefulness of any information, apparatus, product, or process disclosed, or represents that its use would not infringe privately owned rights. Reference herein to any specific commercial product, process, or service by trade name, trademark, manufacturer, or otherwise does not necessarily constitute or imply its endorsement, recommendation, or favoring by the United States Government or any agency thereof. The views and opinions of authors expressed herein do not necessarily state or reflect those of the United States Government or any agency thereof. 


\section{DISCLAIMER}

Portions of this document may be illegible in electronic image products. Images are produced from the best available original document. 
This report was prepared as an account of work sponsored by an agency of the United States Government. Neither the United States Government nor any agency thereof, nor any of their employees, contractors, subcontractors, or their employees, makes any warranty, express or implied, nor assumes any legal liability or responsibility for any third party's use or the results of such use of any information, apparatus, product or process disclosed in this report, nor represents that its use by such third party would not infringe privately owned rights. 
Contract No. W-7405-Eng-26

OPERATIONS DIVISION

RADIOISOTOPE DISTRIBUTION PROGRAM

PROGRESS REPORT FOR AUGUST 1979

\section{E. Lamb}

Work Sponsored by DOE Office of Health and Environmental Research
This NoticE was prepared as an account of work This report was prepared as an accouml Nether the sponsored by the United States Govertes Department of Energy, not any of their employees, nor any of makes contracturs, subcontractioss, or thed or assustes any le $\mathrm{B}^{\text {al }}$ any warranty, express or for the accuracy, completeness liability or responsib information, apparatus, product or or usefuiness of any inforresents that its use would nor process disclosed, or represents the rights.

Date Published - October 1979

NOTICE This document contains information of a preliminary nature. It is subject to revision or correction and therefore does not represent a final report.

OAK RIDGE NATIONAL LABORATORY

Oak Ridge, Tennessee 37830

operated by

UNION CARBIDE CORPORATION

for the

DEPARTMENT OF ENERGY 


\section{THIS PAGE}

\section{WAS INTENTIONALLY LEFT BLANK}


CONTENTS

$\underline{\text { Page }}$

SUMMARY . . . . . . . . . . . . . . . . . . . . 1

RADIOISOTOPE PRODUCTION AND MATERIALS . . . . . . . . . . . 1

Reactor Products Production . . . . . . . . . . . . 1

Iridium-192 Production . . . . . . . . . . . . . . 1

Cyclotron Service Irradiations . . . . . . . . . . . . . I

Cesium-137 Production . . . . . . . . . . . . . 2

Strontium-90 Production . . . . . . . . . . . . 2

Short-Lived Fission Product Production . . . . . . . . . 3

Krypton Enrichment Facility . . . . . . . . . . . . 4

Tritium Operations . . . . . . . . . . . . . . . 4

Krypton-85 Operations . . . . . . . . . . . . . . 4

Packing and Shipping .. . . . . . . . . . . . . . 4

Alpha Handling Facility . . . . . . . . . . . . . . 5

FPDL Operations . . . . . . . . . . . . . . . 5

Miscellaneous . . . . . . . . . . . . . . 5

RADIOISOTOPE SALES . . . . . . . . . . . . . . 5

PUBLICATIONS . . . . . . . . . . . . . . . . . . . . . . . 7

Reports ....................... . 7 


\title{
RADIOISOTOPE DISTRIBUTION PROGRAM \\ PROGRESS REPORT FOR AUGUST 1979
}

\author{
E. Lamb
}

Information is reported on new production inventory status, operational problems, and radioisotope sales.

\section{RADIOISOTOPE PRODUCTION AND MATERIALS}

\section{Reactor Products Production (R. W. Schaich)}

$\frac{\text { Processed Units }}{\frac{\text { Radioisotope }}{\text { Calcium-47 }}} \frac{\text { Amount }(\mathrm{mCi})}{18}$

\section{Iridium-192 Production (R. W. Schaich)}

Five customer irradiation units and ten ORNL HFIR units (RB) containing $113,000 \mathrm{Ci}$ of ${ }^{192} \mathrm{Ir}$ at HFIR discharge date were processed during the month of August, 1979. Eighteen shipments containing 97,000 $\mathrm{Ci}$ of ${ }^{192} \mathrm{Ir}$ were made during this period.

\section{Cyclotron Service Irradiations (M. R. Skidmore)}

During August, 1979, the ORNL 86-Inch Cyclotron operated 18:20 hours for ORNL and Oak Ridge DOE programs for total charges of $\$ 2,905.83$. Non-ORNL irradiations were $145: 15$ hours for total charges of $\$ 27,962.00$. Isotope Sales Inventory irradiations were $63: 15$ hours for total charges of $\$ 9,262.00$.

A cobalt run on August 1 was interrupted due to the rupture of a cooling water hose to the target. On August 5 the startup of a gallium-67 run was delayed due to the failure of an electrical connection on the $R F$ oscillator tube. On August 10 a potentially hazardous condition was discovered before serious damage resulted. Maintenance personnel, while installing a scaffold in the cyclotron area, accidentally disabled the controller on the cooling water system, resulting in the temperature rising in the cyclotron until discovered. On. August 12 a short in the F-134 current limiter tube in the RF system resulted in a delay in the startup of a gallium-67 mu. A cobalt-57 mun was intermupted on August 22 due to the short circuiting of an electrical cable in the current limiter cubicle of the oscillator system. 
Cesium-137 Production (R. W. Schaich)

Processing of two WESF containers of ${ }^{137} \mathrm{CsCl}(130,000 \mathrm{Ci})$ for AECL is in progress. The ${ }^{137} \mathrm{CsCl}$ product inventory follows:

Product Inventory

(Decay calculated through August 31, 1979)

Inventory Material

Cesium-137 chloride powder

Best' Ind. Source

Total Inventory Material

Non-Inventory Material

Reject pellets and sources

Special form cans

Material returned or stored for customer

J. L. Shepherd

New England Nuclear Corporation

Puerto Rico Sources

Lockheed

AECLL powder

Radiation Resources

Gamma Industries

Minn. Mininy \& Mrg. Co.

Total Non-Inventory Material

TOTAL INVENTORY AND NON-INVENTORY MATERIAL
Amount (Ci)

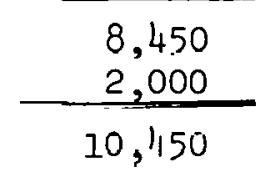

9,050

3,900

60,700

1,500

7,500

18,800

6,600

12,300

8,000

9,900

138,250

148,700

Fabrication Summary

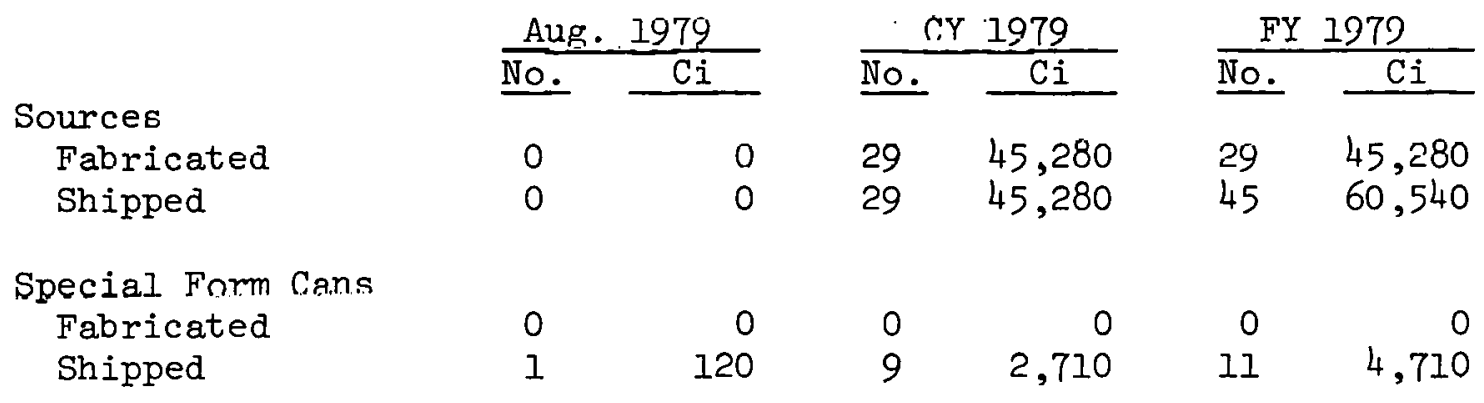

Strontium-90 Production (R. W. Schaich)

The status of ${ }^{90} \mathrm{Sr}$ is given in the table which follows. 
Product Inventiory

(Decay calculated through August 31, 1979)

Inventory Material

${ }^{90} \mathrm{Sr}$ titanate powder $( \pm 5 \%)$

Stock powder cans

Stock solution

Total Inventory Material

Non-Inventory Material

${ }^{90} \mathrm{Sr}$ Fluoride

New England Nuclear Corporation

Calorimeter Standards

Weather Bureau Source

SNAP-7B

SNAP-7C

SNAP material purchase

Total Non-Inventory Material

TOTAL INVENTORY AND NON-INVENTORY MATERIAL
Amount (Ci)

$$
\begin{array}{r}
0 \\
2,850 \\
170 \\
3,020
\end{array}
$$

$$
\begin{array}{r}
68,500 \\
170 \\
3,800 \\
10,800 \\
148,800 \\
136,100 \\
123,600 \\
515,170
\end{array}
$$

518,190

Fabrication Summary

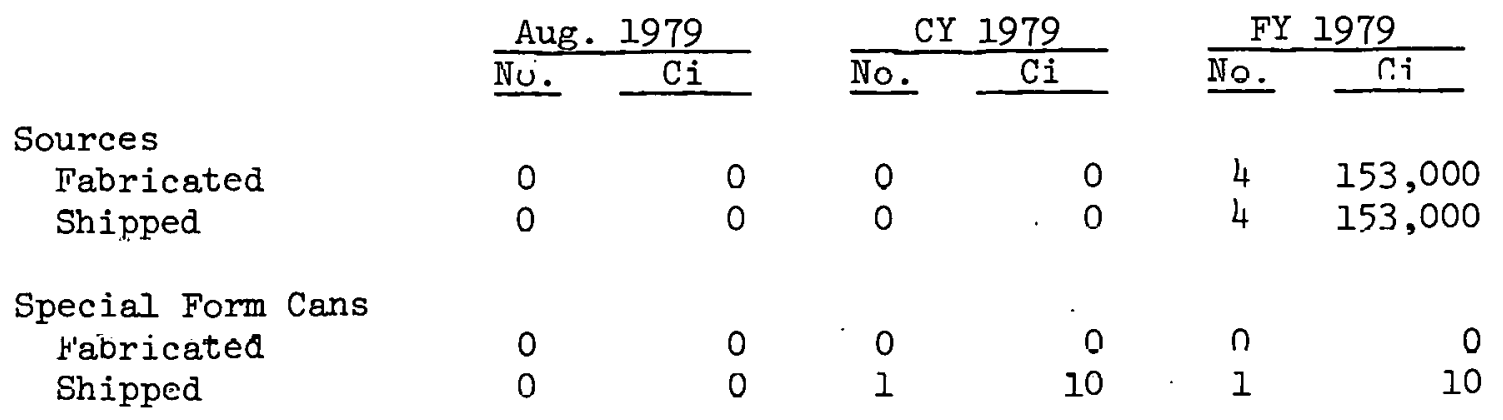

Short-Lived Fission Production ( $H$. Bailey)

The startup of the Short-Lived Fission Product Facility proceeded on schedule. Xenon-133 production had some minor startup problems but these have been resolved, and ${ }^{133} \mathrm{Xe}$ is on a routine schedule of processing every other week. 
Krypton Enrichment Facility (J.R. DeVore)

T'he north bank of ${ }^{85} \mathrm{Kr}$. Thermal Diffusion Columns (TDC) remains shut down as an energy conservation measure. During this report period, leak testing and repairs were initiated on the north bank to place it in operation if additional capacity is required in the future.

The south bank operated normally until 8/23/79 when the three columns were shut down and unloading was begun. The center of $\mathrm{C}$ column, which should contain the $40 \%$ enriched material, was unloaded first and no problems were encountered. Tails were removed from the other two columns. Unloading should be complete by mid-September.

Design of the enriched ${ }^{85} \mathrm{Kr}$ storage and serrpling system is approximatcly 95\% complete. Removal of the old storage equipment has not been started due to lack of manpower.

Tritium Operations ( $J . R$. DeVore)

Tritium exposure levels have been reduced to acceptable levels. The preliminary safety analysis report work has again started, with publication still anticipated by $1 / 1 / 80$.

Installation of the urethane floor covering was completed.

Engineering has released design drawings of the tritium handling system, with the exception of the piping and instrumentation portions which should be completed in september.

The tritium duct monitor was calibrated, but sample results are not yet available.

Twelve gas cylinders, one glass ampule, and ten nonreturnable containers were loaded with $157,000 \mathrm{Ci}$ of tritium for shipment to customers.

Krypton-85 Operations (J.R. DeVore)

Twenty-eight gas cylinders were loaded with 1,130 ni of ${ }^{85} \mathrm{Kr}$ for shipment to customers.

Packing and Shipping (R. D. Johnston)

One hundred and ninety-one packages were processed and shipped during the reporting period. The total weight shipped was 199,000 pounds. 
Radioactive
Solid. Shipments

52

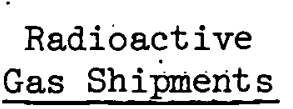

47
Radioactive Liquid Shipments

60
Empty

Containers Total

15

174

Alpha Handling Facility (R. D. Johnston)

Two packages of alpha-emitting material was prepared for shipment--one 10-gram shipment of ${ }^{238} \mathrm{Pu}$ and one package of ${ }^{24} \mathrm{Pu}$.

FPDL Operations (F. V. Wizziams)

The equipment for loading ${ }^{147} \mathrm{Pm}_{2} \mathrm{O}_{3}$ powder into capsules was installed in Cell 10, and 79 inner capsules were loaded--of which 49 capsules were cleaned and prepared for seal welding and loading into the outer capsules.

The dismantling of Cell 19, a steel-shielded cell atop the main cell block, was begun.

\section{Miscellaneous (R. W. Schaich)}

A new ${ }^{133} \mathrm{Xe}$ loadout system was placed in operation during the month. Minor shielding will be added to reduce personnel exposure.

The design of an electropolisher system for FPDL decontamination operations was completed. Installation of this equipment has been delayed until 1980. Estimated costs for this project are $\$ 224,000$.

The fabrication of 23 new containers for use in the ${ }^{85} \mathrm{Kr}$ and tritium business is $275 \%$ complete. Delivery is now scheduled for October, 1979.

An engineering work order for preliminary planning and cost estimate for decommissioning Building 3505 is progressing on schedule.

A new tritium cylinder decontamination station was designed and fabrication. initiated in the Plant and. Equipment shops. Completion of this station is scheduled for September, 1979.

\section{RADIOISOTOPE SALES}

$$
\text { J. E. Ratledge }
$$

Shipments made during the month that may be of interest are listed below: 
Customer

Isotope

Amount

Large Quantities

Battelle Northwest

Krypton-85 $\quad 100 \mathrm{Ci}$

Radiochemical Centre, Ltd.

Krypt on-85

$100 \mathrm{Ci}$

Krypton-85 $250 \mathrm{Ci}$

Trio Tech International

Minnesota Mining \& Manufacturing

Promethium-147

$1,000 \mathrm{Ci}$

Radiochemical Centre, Ltd.

Promethium-147

4,848 Ci

Radium-Chemie Ltd.

Gollob Analytical Service

ICN Pharmaceuticals

Promethium-147

$1,008 \mathrm{Ci}$

Tritium

Lawrence Livermore Laboratory

Tritium

Tritium

$1,000 \mathrm{Ci}$

Mer's \& Bentel1 Nuclear

'I'ritiun

New Fingland Nuclear

Tritium

Radium-Chemie

Saunders-Roe Development

Tritium

Tritium

Self-Powered Lighting

United States Radium Corporation

Tritium

Tritium

$2,000 \mathrm{Ci}$

$7,739 \mathrm{Ci}$

$30,000 \mathrm{Ci}$

$8,000 \mathrm{Ci}$

$30,000 \mathrm{Ci}$

$60,000 \mathrm{Ci}$

$16,000 \mathrm{Ci}$

$10,000 \mathrm{Ci}$

Withdrawn Items

ORNL Dept. of Quality Assurance

and Inspection

ORNL Chemical Technology

New England Nuclear

Iodine-131

Iodine-I3I

Carbon-14

$81 \mathrm{mCi}$

$10 \mathrm{mCi}$

$10 \mathrm{Ci}$

Items Used in Cooperative Programs

UCLA

Univereity of Kentucky

Platinum-195m

Plat inum-195m
$1.5 \mathrm{mCi}$

$20 \mathrm{MC} \mathrm{i}$

The radioisotope sales and shipments for the first eleven months of fiscal year 1978 and fiscal year 1979 are given in Table 1.

Table 1. Radioisotope Sales and Shipments

\begin{tabular}{lcc}
\hline \multicolumn{1}{c}{ Item } & $\begin{array}{c}10 / 1 / 77 \text { through } \\
8 / 31 / 78\end{array}$ & $\begin{array}{c}10 / 1 / 78 \text { through } \\
8 / 31 / 79\end{array}$ \\
\hline Inventiory Ttems & $\$ 1,33,799$ & $\$ 1 / 1,1,67$ \\
$\quad$ Tritium & $1,551,816$ & $1,712,851$ \\
Major Products & 523,473 & 447,440 \\
$\quad$ Iridium-192 & 845,511 & $1,296,125$ \\
Radioisotope Services & 270,139 & 312,942 \\
Cyclulron Irradialions & 304,468 & 421,488 \\
Miscellaneous Processed Materials & 206,195 & 68,469 \\
Packing and Shipping & 201,115 & 167,115 \\
$\quad$ Total & $\$ 4,056,516$ & $\$ 4,675,897$ \\
Number of Shipments & 2,410 & 1,939
\end{tabular}




\section{PUBLICATIONS}

$\beta$

Reports

E. Lamb, Radioisotope Distribution Progrom Progress Report for July, 2979, ORNL/TM-7047, Oak Ridge National Laboratory (in press). 


\section{THIS PAGE}

WAS INTENTIONALLY

LEFT BLANK 
ORNL/TM-7088

\section{INTERNAL DISTRIBUTION}

1. F. N. Case

2. W. R. Casto

3. J.A. Cox

4. P. W. Hembree

5. R. F. Hibbs

6. F. F. Knapp

7. E. Lamb

8. B. F. Maskewitz, RSIC

9. C. L. Ottinger

10. H. Postma
11. M. E. Ramsey

12. J. E. Ratledge

13. C. R. Richmond

14. R. W. Schaich

15. M. R. Skidmore

16. M. J. Skinner

17-18. Central Research Library

19-20. Laboratory Records Department

21. Laboratory Records - RC

22. Document Reference Section

EXTERNAL DISTRIBUTION

23. J. N. Maddox, DOE-EV, Washington, DC

24. H. A. O'Brien, LASL, Los Alamos, New Mexico

25. L. D. Perrigo, PNL, Richland, Washington

26. L. G. Stang, Jr., BNL, New York

27. H. H. Van Tuyl, PNL, Richland, Washin-ton

28. W. H. Weyzen, DOE-OHER, Washington, DC

29. Donner Laboratory Library, Univ. of California, Berkeley, CA

30. Assistant Manager for Energy Research and Development, DOE-ORO

31-32. Technical In Cormation Center 